\title{
Croatian Journal of Food Science and Technology
}

\section{Effect of extraction variables on total phenol yield in some selected legumes indigenous to Nigeria}

\section{SAMAILA JAMES ${ }^{1 *}$,TITUS UGOCHUKWU NWABUEZE ${ }^{2}$, GREGORY I. ONWUKA ${ }^{2}$, JOEL NDIFE ${ }^{2}$, SULEIMAN JAMES AMUGA ${ }^{3}$}

${ }^{1}$ Department of Food Science and Technology, Federal University of Technology, Minna, Nigeria

${ }^{2}$ Department of Food Science and Technology, College of Applied Food Sciences, Michael Okpara University of Agriculture, Umudike, Nigeria

${ }^{3}$ Department of Biological Sciences, Federal University Kashere, Gombe State

\begin{tabular}{l}
\hline A R T I L E I N F O \\
\hline Article history: \\
Received: June 4, 2019 \\
Accepted: November 22, 2019 \\
\hline Keywords: \\
Indigenous legumes \\
extraction variables \\
total phenol
\end{tabular}

\section{Introduction}

Phytochemicals are simply bioactive plant substances often referred to as secondary metabolites which provide health benefit (Tan et al., 2013; Silva et al., 2007; Singh et al., 2016). Previously, they were considered as unwanted components in food. Their extensive studies have resulted in the discovery of many health benefits. Phytochemicals such as phenolic acids, carotenoids, tocopherols, terpenes are diverse in nature and are majorly found in fruits and vegetables, cereals and pulses and in the plant spices (Wu et al., 2004; Towo et al., 2003; Sultana et al., 2007). Bambaranut is grown extensively in Nigeria and despite its high and balanced protein content and appealing cooked or roasted flavour, it is one of the most underutilized legumes in the country.
Bambaranut is a rich source of protein (20 - $25 \%)$ which has more methionine than other legumes and contains 6 - $12 \%$ of lipids (NRC, 2006; Stephens, 2011). The bean is rich in mineral elements, especially phosphorus, magnesium, calcium, iron, copper, zinc and exhibits antioxidant capacity (Yao et al., 2005). Cowpea is one of the most important pulse crops native to central Africa. The seeds are referred to as 'vegetable meat' due to the high amount of protein of the grain with better biological value on a dry weight basis (DWB). The seeds on DWB contain $23.40 \%$ of proteins, $1.80 \%$ of fat and $60.30 \%$ of carbohydrates (Gupta, 1988). Compared to animal proteins, the seeds are high in minerals such as calcium and iron. Its vitamins (thiamin, riboflavin and niacin) compare favourably with the ones in lean meat and fish, while the iron content compares favourably with milk (Platt, 1962; Adams, 1984; Achuba, 2006).

*Corresponding author E-mail: samaila.james@futminna.edu.ng 
Pigeon pea is an important food legume of the semi-arid tropics of Asia and Africa. It is the second most important pulse crop next to chickpea (Onim et al., 1985; Achieng and Odey, 2007). It is a good source of dietary minerals such as calcium, phosphorus, magnesium, iron, sulphur and potassium (Achieng and Odeny, 2007) and water-soluble vitamins especially thiamine, riboflavin and niacin (Salunkhe et al., 1986; Bantilan and Parthasarathy, 1997).

Studies have shown that legumes constitute a large reservoir of phytochemicals which are beneficial in preventing and managing degenerative diseases $(\mathrm{Hu}$, 2003; Jacobs and Gallaher, 2004; Enujiugha, 2010). In recent years, research efforts have been intensified on the possibilities of utilization of natural sources of bioactive compounds for the dietary management of certain chronic diseases due to attendant deleterious effects associated with the use of synthetic compounds. Despite the beneficial roles of these complex compounds, there is a dearth of information on their availability in underutilised legumes. Therefore, this study was aimed at evaluating the effects of solvent type, solvent concentration,extraction time and extraction temperature on the yield of total phenol. This would help in optimising the recovery of total phenol in lesser legumes under investigation.

\section{Materials and methods}

\section{Materials}

Indigenous and underutilised legumes for this study were bambaranut (Vigna subterranean (L.) Verdc. (Fabaceae)), red bean, cowpea (Vigna unguiculata (L.) Walp) and pigeon pea (Cajanus cajan).

The samples were procured in December, 2017 from Umuahia Local Market and botanically identified by the Department of Crop Production, Federal University of Technology, Minna, Nigeria.

\section{Reagents}

Extraction solvents used in this study were acetone, manufactured by Lobal Chemie Pvt. Ltd., India with CAS No. (64-17-5), ethanol, manufactured by Guangdong Guanghua Sci-Tech. Co. Ltd. India with CAS No. (67-64-1) and methanol manufactured by Lobal Chemie Pvt. Ltd., India with CAS No. (67-561). All the extraction solvents were procured from Finlab Abuja, Nigeria.

\section{Extraction variables for total phenolic compounds}

Extraction conditions for total phenolic recovery were based on the following factors: solvent type, solvent concentration,extraction time and extraction temperature. One factor was varied at a time while keeping others constant. Fixed factors were particle size of $0.50 \mathrm{~mm}$ and the solvent-to-solid ratio of 10:1 (Tan et al., 2013).

Total phenolic was extracted in $60 \%(\mathrm{v} / \mathrm{v})$ methanol, $60 \%(\mathrm{v} / \mathrm{v})$ ethanol and $60 \%(\mathrm{v} / \mathrm{v})$ acetone at extraction time of $180 \mathrm{~min}$ and extraction temperature of $28 \pm 2{ }^{\circ} \mathrm{C}$. The optimal extraction solvent was selected upon the highest value of total phenolic compound TPC (mg GAE/100 g DW).

Total phenol was extracted from the sample using a solvent that gave the highest content. The best solvent was used at different concentrations ranging from $20 \%(\mathrm{v} / \mathrm{v})$ to $100 \%(\mathrm{v} / \mathrm{v})$ for the extraction, while holding the other two independent variables, which were the extraction time $(180 \mathrm{~min})$ and extraction temperature $\left(28 \pm 2{ }^{\circ} \mathrm{C}\right)$, at a constant level. The optimal solvent concentration was selected upon the highest value of TPC (mg GAE/100 g DW).

Based on the solvent type and solvent concentration selections giving optimal extraction of phenolics, extraction was repeated at different periods ranging from 30, 40 and $50 \mathrm{~min}$ at ambient temperature $\left(28 \pm 2{ }^{\circ} \mathrm{C}\right)$. The optimal extraction time was selected upon the highest value of TPC (mg GAE/100 g DW).

Upon the evaluation of optimal solvent type, solvent concentration and extraction time, extraction was performed at different temperatures ranging from $40, \quad 50$ and $60{ }^{\circ} \mathrm{C}$. The optimal extraction temperature was selected upon the highest value of TPC (mg GAE/100 g DW).

\section{Determination of total phenols in the extract}

Folin-Ciocalteu method as described by Rajha et al. (2014) was used. An aliquot of $10 \mu \mathrm{L}$ of the sample solution was mixed with $100 \mu \mathrm{L}$ of commercial FolinCiocalteu reagent and $1580 \mu \mathrm{L}$ of water. After a brief incubation at room temperature $(5 \mathrm{~min}), 300 \mu \mathrm{L}$ of saturated sodium carbonate was added. The colour generated was read after $2 \mathrm{~h}$ at room temperature at $760 \mathrm{~nm}$ using a UV-Vis spectrophotometer (UV-9200, UK). The correlation between the absorbance and gallic acid concentrations creates a calibration standard curve. The phenolic compounds concentration of the samples was expressed as gallic acid equivalents in $\mathrm{mg} / \mathrm{L}$, then the Total Phenolic Compounds yields (TPC) were calculated by transforming milligrams of Gallic Acid Equivalent (GAE) per litre (mg GAE/L) into grams of GAE per $100 \mathrm{~g}$ dry matter (g GAE/100 g DM). 


\section{Statistical analysis}

The total phenol content from each sample was determined in triplicate. The data generated were analysed using the analysis of variance (Steel and Torrie, 1980). The difference between mean values was determined by the least significant difference test. Significance was accepted at the 5\% probability level. Processed data were expressed in a bar chart format as mean \pm standard deviation (SD).

\section{Results and discussion}

\section{Solvent types evaluation on total phenol content}

The effect of solvent type on total phenol content is shown in Fig. 1. The three solvents evaluated (acetone, ethanol and methanol) did not significantly ( $p>0.05$ ) affect the total phenol content of bambaranut, red bean and pigeon pea, while in cowpea ethanol gave significantly $(\mathrm{p}<0.05)$ higher yield of total phenol $(118.65 \mathrm{mg} / 100 \mathrm{~g})$. To rationalize the disparity in the total phenol yield of different food materials Nobre et al. (2005), Liyana-Patthirana and Shahidi (2004) and Chew et al. (2014) reported that extraction solvent, solvent concentration, food particle size, extraction time and temperature, extraction $\mathrm{pH}$, plant species and agronomic practice play significant roles. The extraction of total phenol is dependent on the ability of the extraction solvent to dissolve the compound in the food matrix. Goli et al. (2004) and Nur Syukriah et al. (2014) revealed that phytochemicals are either water soluble such as polyphenols or lipid soluble such as carotenoids. Since both polar and nonpolar solvents evaluated gave statistically similar total phenol yield in the legume samples evaluated, it can be deduced that the phenol profile of legumes under investigation are spread in both polarities. Though, solvent types did not significantly affect phenol yield in bambaranut, red bean and pigeon pea, but from the point of view the highest total phenol yield, economy and safety, ethanol was selected for bambaranut, while methanol was selected for pigeon pea and red bean for subsequent evaluation of other extraction variables.

Effect of ethanol concentrations $(20-100 \%, v / v)$ on bambaranut total phenol content

The effect of ethanol concentrations on bambaranut total phenol content is shown in Fig. 2. The result shows that ethanol concentrations did not significantly $(p>0.05)$ affect the total phenol content except at $90 \%$ concentration $(\mathrm{v} / \mathrm{v})$ which was significantly $(\mathrm{p}<0.05)$ low $(135.54 \mathrm{mg} / 100 \mathrm{~g})$.

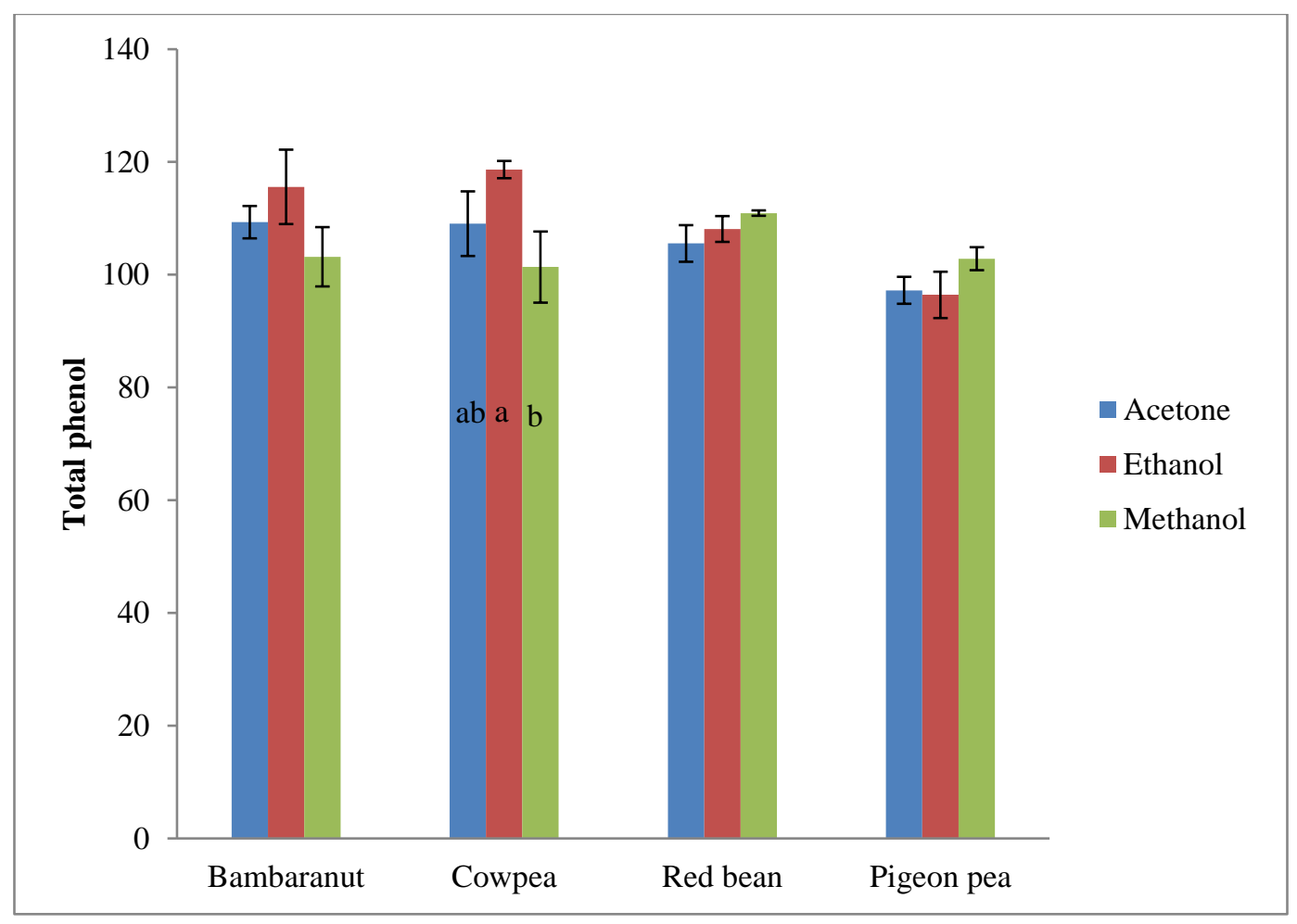

Fig. 1. Effect of solvent types on total phenol content 


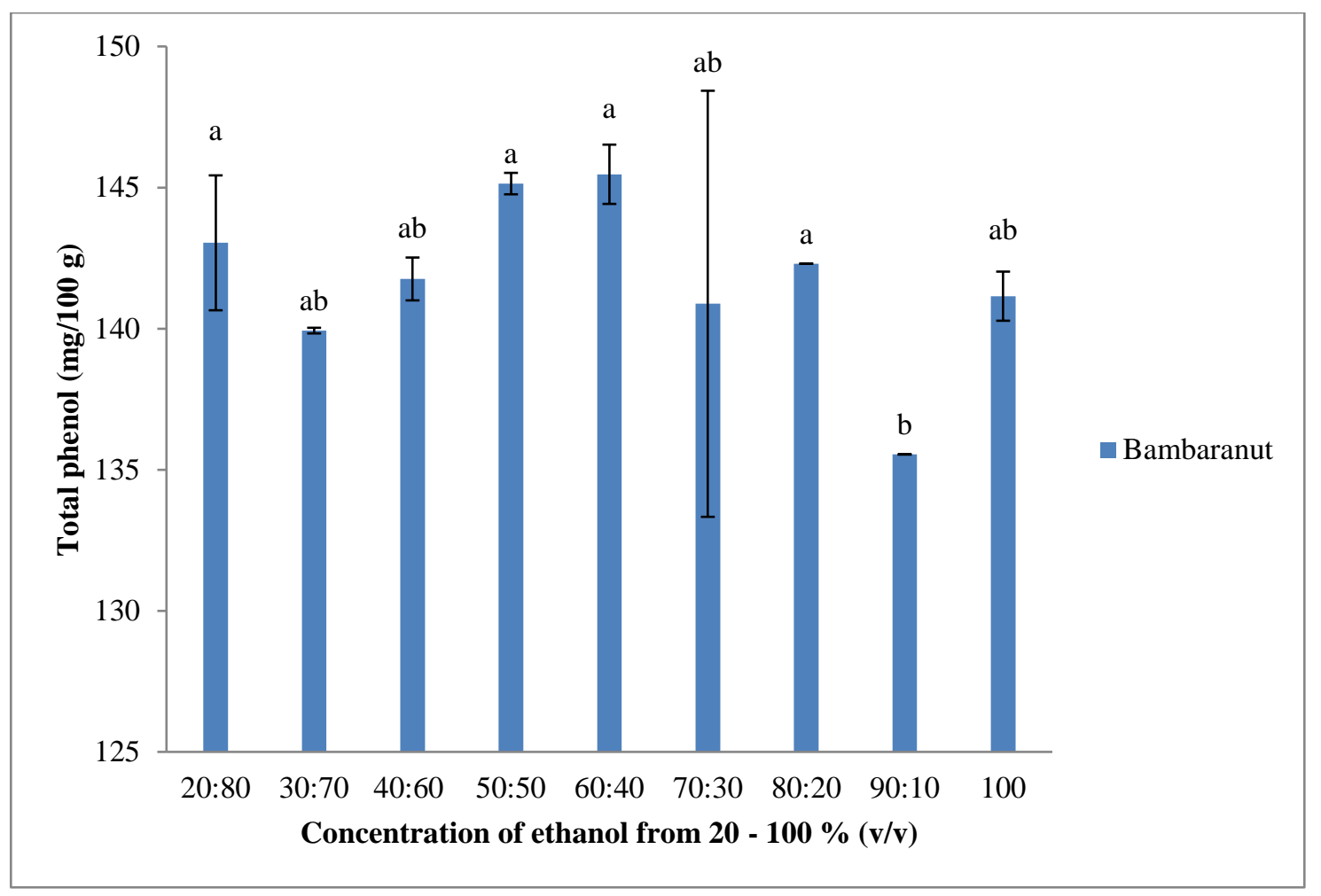

Fig. 2. Effect of ethanol concentrations on bambaranut total phenol content

The total phenol extract ranged from $135.54 \mathrm{mg} / 100 \mathrm{~g}$ to $145.47 \mathrm{mg} / 100 \mathrm{~g}$. The result suggests that bambaranut phenol content at different ethanol concentrations is soluble in both low, moderate and high ethanol concentrations. Furthermore, different concentrations of solvent used had no effect on the solubility, swelling power of the plant matrix and phenol extractability. Therefore, bambaranut contains diverse phenolic compounds with diverse polarities. This agrees with Chew et al. (2011) who reported a high yield of total phenol in Centella asiatica at different ethanol concentrations. Based on the result of this study, the highest total phenol content was attained at $60 \%$ ethanol $(\mathrm{v} / \mathrm{v})$; hence, this concentration was chosen for time and temperature optimization.

\section{Ethanol concentration evaluation on cowpea total phenol content}

Fig. 3 shows the effects of ethanol concentrations $(20-$ $100 \%, \mathrm{v} / \mathrm{v})$ on cowpea total phenol content. The result shows that ethanol concentration significantly $(\mathrm{p}<0.05)$ affected the total phenol content of cowpea. The value ranged from $138.85 \mathrm{mg} / 100 \mathrm{~g}$ to $151.82 \mathrm{mg} / 100 \mathrm{~g}$. The highest yield of phenol $(151.82 \mathrm{mg} / 100 \mathrm{~g})$ was given by $90 \%(\mathrm{v} / \mathrm{v})$ ethanol and this was followed by $30 \%(\mathrm{v} / \mathrm{v})$ ethanol $(147.91 \mathrm{mg} / 100 \mathrm{~g})$. Ethanol concentrations at $20 \%, 40 \%, 60 \%$ and $70 \%$ (v/v) did not significantly $(p>0.05)$ differ in their total phenol content, while ethanol concentrations at 50\%, 80\% and $100 \%(\mathrm{v} / \mathrm{v})$ were significantly $(\mathrm{p}<0.05)$ low in their total phenol $138.85 \mathrm{mg} / 100 \mathrm{~g}, 140.06 \mathrm{mg} / 100 \mathrm{~g}$ and $140.88 \mathrm{mg} / 100$ $\mathrm{g}$, respectively. A general principle in solvent extraction is that polar solvent dissolves polar compounds while non-polar solvent dissolves non-polar compounds. This implies that the polarity of the extraction solvent must be similar to the polarity of the phytochemicals (Zhang et al., 2007 and Chew et al., 2011). Thus, cowpea bean contains diverse phenolic compounds with different polarities. The highest total phenol content $151.82 \mathrm{mg} / 100 \mathrm{~g}$ was achieved at 90\% (v/v) ethanol. Therefore, it can be suggested that most of the phenolic compounds in cowpea bean are less polar in nature.

\section{Effect of methanol concentrations $(20-100 \%, v / v)$ on red bean total phenol content.}

The total phenol yield as influenced by methanol concentrations on red bean is shown in Fig. 4. The result shows that methanol concentrations significantly $(\mathrm{p}<$ 0.05 ) affected the total phenol yield. Methanol at $100 \%$ significantly gave the highest $(147.30 \mathrm{mg} / 100 \mathrm{~g})$ total phenol. This was followed by methanol concentration used at $90 \%(\mathrm{v} / \mathrm{v})$ which gave $141.89 \mathrm{mg} / 100 \mathrm{~g}$ total phenol while $80 \%$ methanol (v/v) gave the lowest yield $(131.55 \mathrm{mg} / 100 \mathrm{~g})$. The total phenol range in red bean $(131.55-147.30 \mathrm{mg} / 100 \mathrm{~g})$ is low compared with other pulses $5794.63 \mathrm{mg} / 100 \mathrm{~g}$ in chickpea, $3365.34 \mathrm{mg} / 100 \mathrm{~g}$ in faba bean and $5614.36 \mathrm{mg} / 100 \mathrm{~g}$ in fenugreek seed (Salem et al., 2014). 


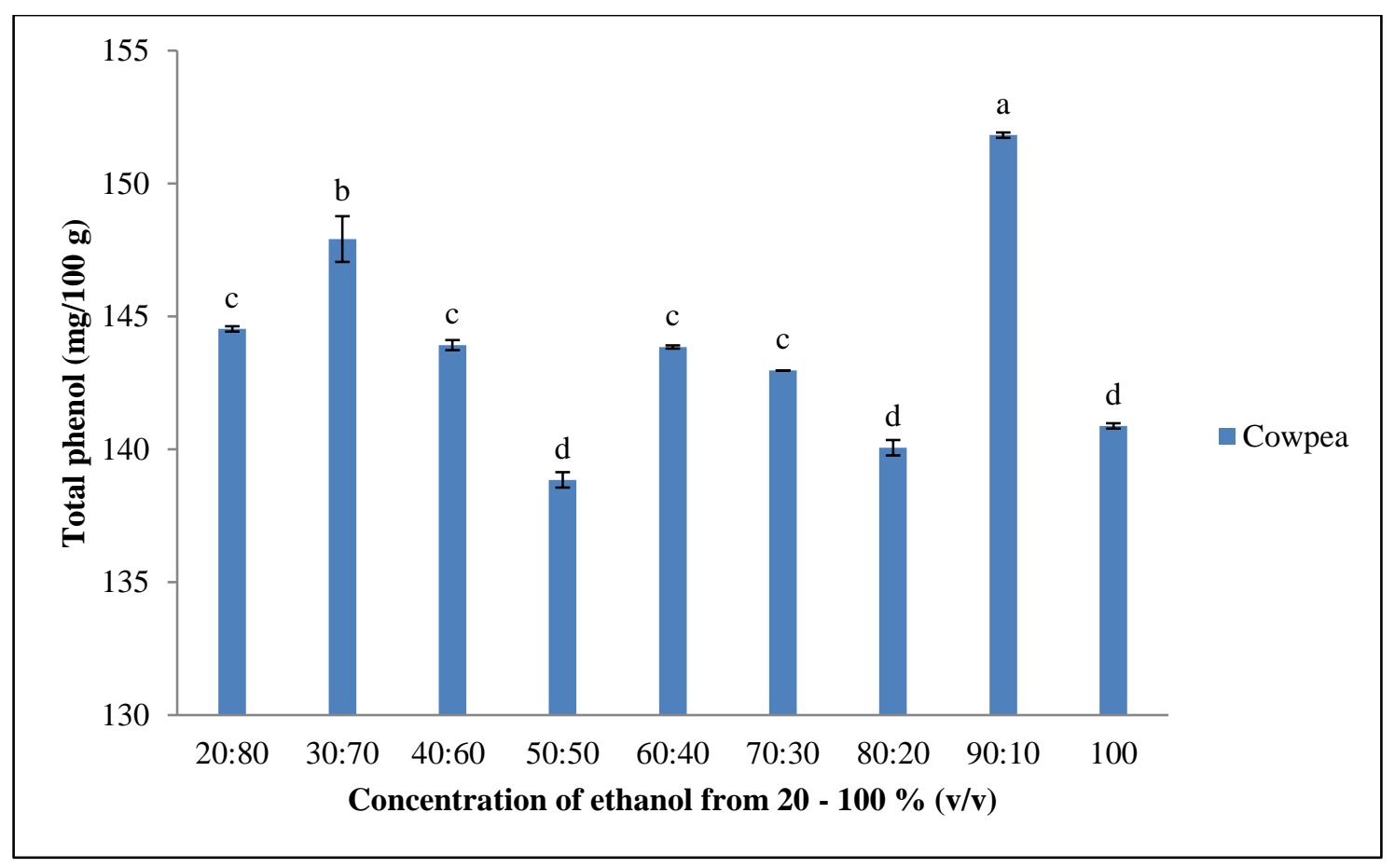

Fig. 3. Effect of ethanol concentrations on cowpea bean total phenol content

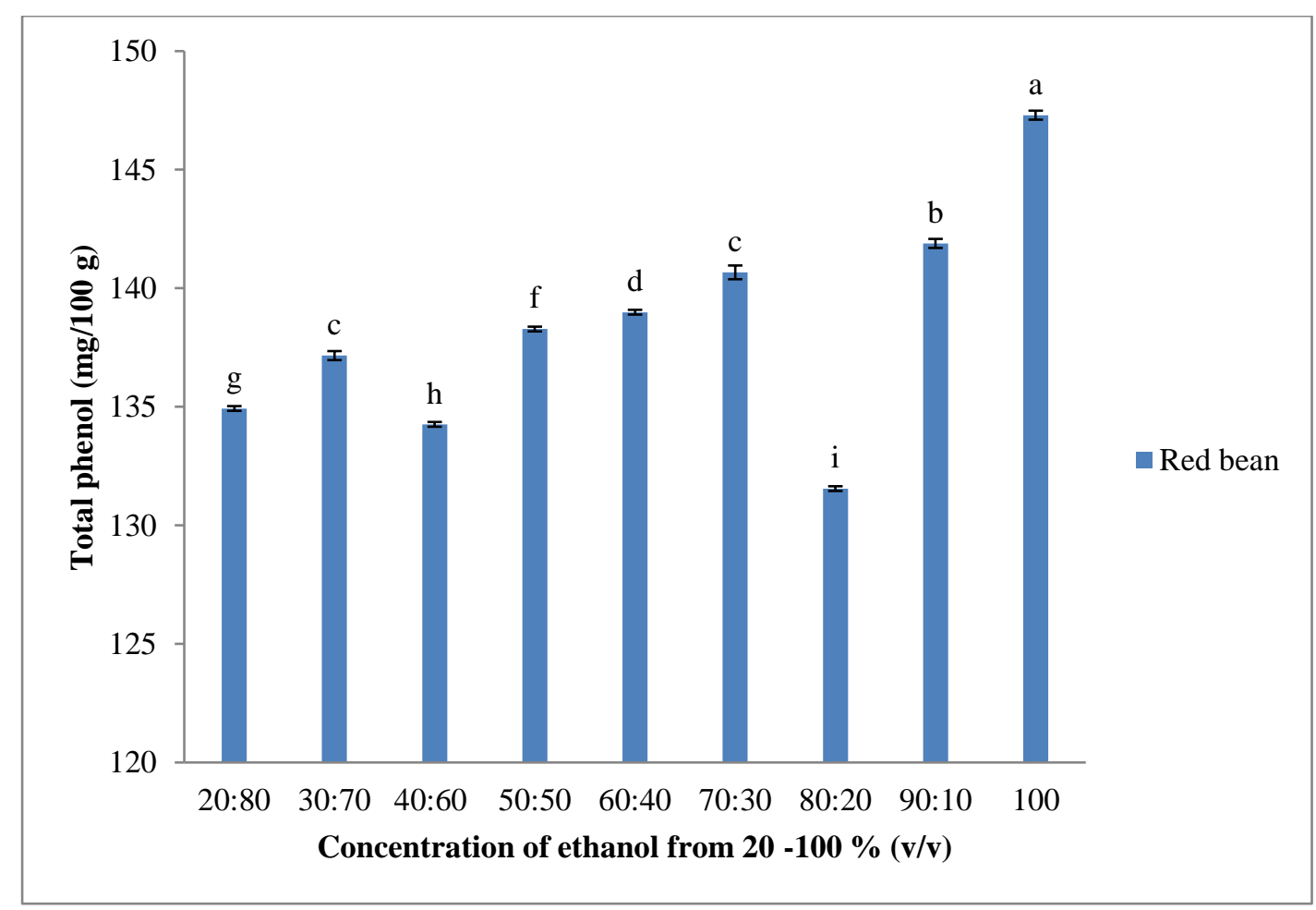

Fig. 4. Effect of methanol concentrations on red bean total phenol content

The result of this study shows that less polar systems, $90 \%$ and $100 \%(\mathrm{v} / \mathrm{v})$, gave the highest yield of total phenol in red bean. This suggests that red bean phenol profile is more concentrated in low polar medium. The result of this finding agrees with Sultana et al. (2007) who reported a high yield of total phenol from the plant matrix extracted in a high concentration of methanol. For time and temperature evaluation of total phenol yield in red bean, $100 \%$ methanol $(\mathrm{v} / \mathrm{v})$ which significantly gave high yield, was chosen. 


\section{Methanol concentrations evaluation on pigeon pea total phenol content}

The effect of methanol concentrations, $20-100 \%$ $(\mathrm{v} / \mathrm{v})$ on pigeon pea total phenol content is shown in Fig. 5. The result shows that methanol at $100 \%(\mathrm{v} / \mathrm{v})$ concentration gave the highest yield of total phenol $(143.31 \mathrm{mg} / 100 \mathrm{~g})$. However, methanol used at low concentrations $20 \%$ and $30 \%(\mathrm{v} / \mathrm{v})$ gave significantly $(\mathrm{p}<0.05)$ low values, $136.01 \mathrm{mg} / 100 \mathrm{~g}$ and $135.81 \mathrm{mg} / 100 \mathrm{~g}$ total phenol, respectively. This result suggests that pigeon pea total phenol profile is less polar. The result here agrees with Sultana et al. (2007) and Anwar and Przybylski (2012) who reported a high yield of total phenol in a high concentration of methanol in plant material.

The value obtained in this study, $1.33 \mathrm{mg} / \mathrm{g}$ to 1.43 $\mathrm{mg} / \mathrm{g}$, is lower compared with $9.44 \mathrm{mg} / \mathrm{g}$ in pigeon pea extracted in methanol (Rani et al., 2014). The variation in total phenol content within the same species but different traits could be attributed to agronomic practices, different extraction variables such as extraction temperature, extraction time, plant matrix size among others (Kraushofer and Sontag, 2002;
Lorenc-Kukula et al., 2005; Kasote et al., 2011). For the evaluation of time and temperature variables on pigeon pea total phenol, an exclusively nonpolar concentration, $100 \%$ methanol (v/v), was chosen.

\section{Influence of extraction time variable on total phenol} content of the legumes

The effect of extraction time (min) on the yield of total phenol of legume samples is shown in Fig. 6. The results show that extraction time significantly $(\mathrm{p}<0.05)$ affected the total phenol yield in bambaranut and cowpea. However, extraction time had no effect on the total phenol yield of red bean and pigeon pea. Extraction time is an important parameter that influences the total phenol recovery. It plays a role in minimising total cost and energy of the process (Chew et al., 2011 and Tan et al., 2013). Longer extraction time exposes phenolic compounds to oxygen, light and unfavourable temperature which increases the chance of their oxidation (Naczk and Shahidi, 2006; Chirinos et al., 2007; Chew et al., 2011).

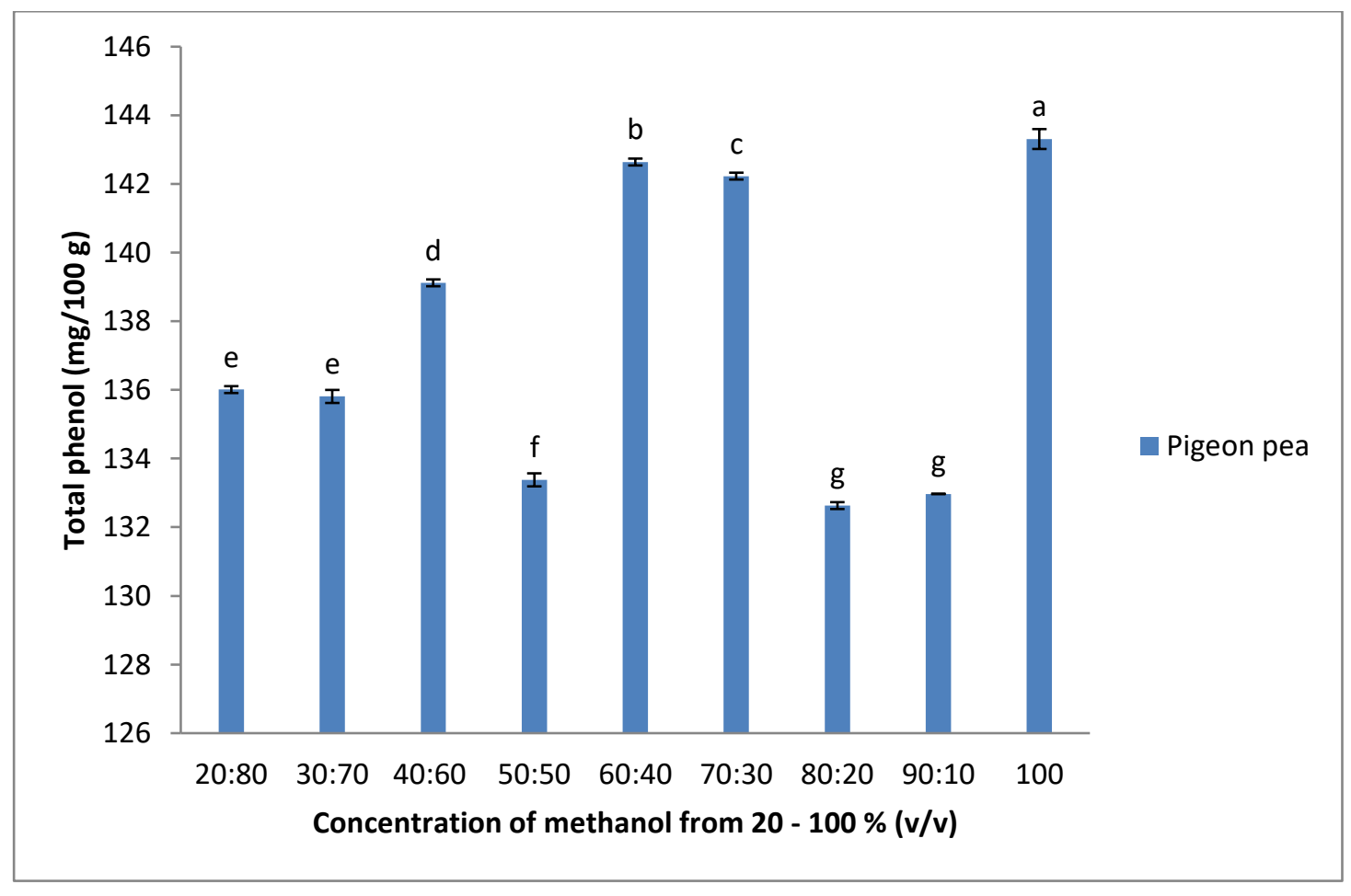

Fig. 5. Effect of methanol concentrations on pigeon pea total phenol content 


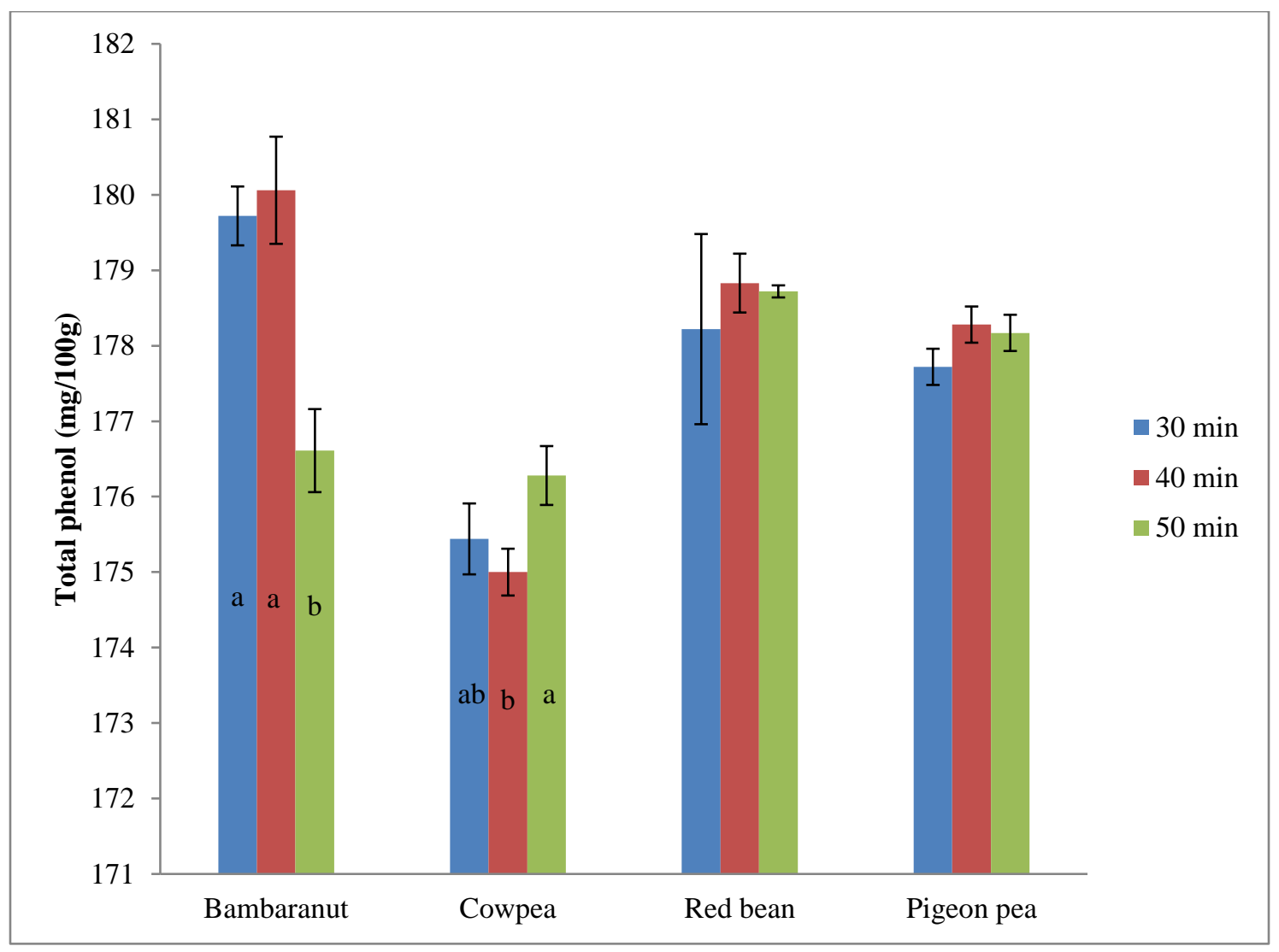

Fig. 6. Effect of extraction time on total phenol content

Furthermore, long extraction time predisposes the phenolic compounds to endogenous enzyme activity which reduces the total phenol recover, increases the potential loss of solvent via evaporation, which directly affects the loss of solvent-to-solid ratio extraction, hence, it is uneconomical from industrial point of view (Silva et al., 2007; Kuljarachanan et al., 2009; Chew et al., 2011; Tan et al., 2013). Cowpea total phenol extracted in $90 \%(\mathrm{v} / \mathrm{v})$ ethanol (176.28 $\mathrm{mg} / 100 \mathrm{~g})$ at $50 \mathrm{~min}$ gave significantly $(\mathrm{p}<0.05)$ higher total phenol than those extracted at $40 \mathrm{~min}$ and $60 \mathrm{~min}$. Bambaranut total phenol extracted in $60 \%$ ethanol $(\mathrm{v} / \mathrm{v})$ at $40 \mathrm{~min}$ $(180.06 \mathrm{mg} / 100 \mathrm{~g})$ was significantly $(\mathrm{p}<0.05)$ higher than those extracted at $30 \mathrm{~min}$ and $50 \mathrm{~min}$. The gradual increase in the total phenol with corresponding increase in extraction time in cowpea $(175.00-176.28 \mathrm{mg} / 100 \mathrm{~g})$ can be well explained by Fick's second law of diffusion which reveals that a final equilibrium will be attained between the solution concentration in the solid matrix and the solvent after a particular duration (Pinelo et al., 2006; Silva et al., 2007). Therefore, the temperature evaluation on total phenol content at 50 min was chosen. However, the phenomenon of solvent equilibration did not apply to bambaranut whose high total phenol contents were achieved at a shorter time (30 $\mathrm{min}$ ). This can be attributed to possible oxidation of their total phenol at the extended time (40 $\mathrm{min}$ and $50 \mathrm{~min}$ ) adopted in this study. This view agrees with the findings of Chew et al. (2011) and Tan et al. (2013) who reported a low yield of total phenol in plant matrix at an extended time. Therefore, for temperature evaluation of 40 min extraction time was chosen for bambaranut. Since extraction time did not significantly $(p>0.05)$ affect the total phenol recovery in red bean and pigeon pea, hence, extraction time of $40 \mathrm{~min}$, which gave the highest yield, was chosen.

\section{Extraction temperature evaluation on legume total phenol content}

The effect of temperature variations $\left(40{ }^{\circ} \mathrm{C}, 50{ }^{\circ} \mathrm{C}\right.$, and $60{ }^{\circ} \mathrm{C}$ ) on total phenol yield of the legume samples after examining the best solvent type, solvent concentration and optimal extraction time is shown in Fig. 6. The results show that extraction temperature significantly $(\mathrm{p}<0.05)$ affected total phenol yield in bambaranut, red bean and pigeon pea. However, the extraction temperature did not significantly $(p>0.05)$ affect the total phenol content of cowpea. 


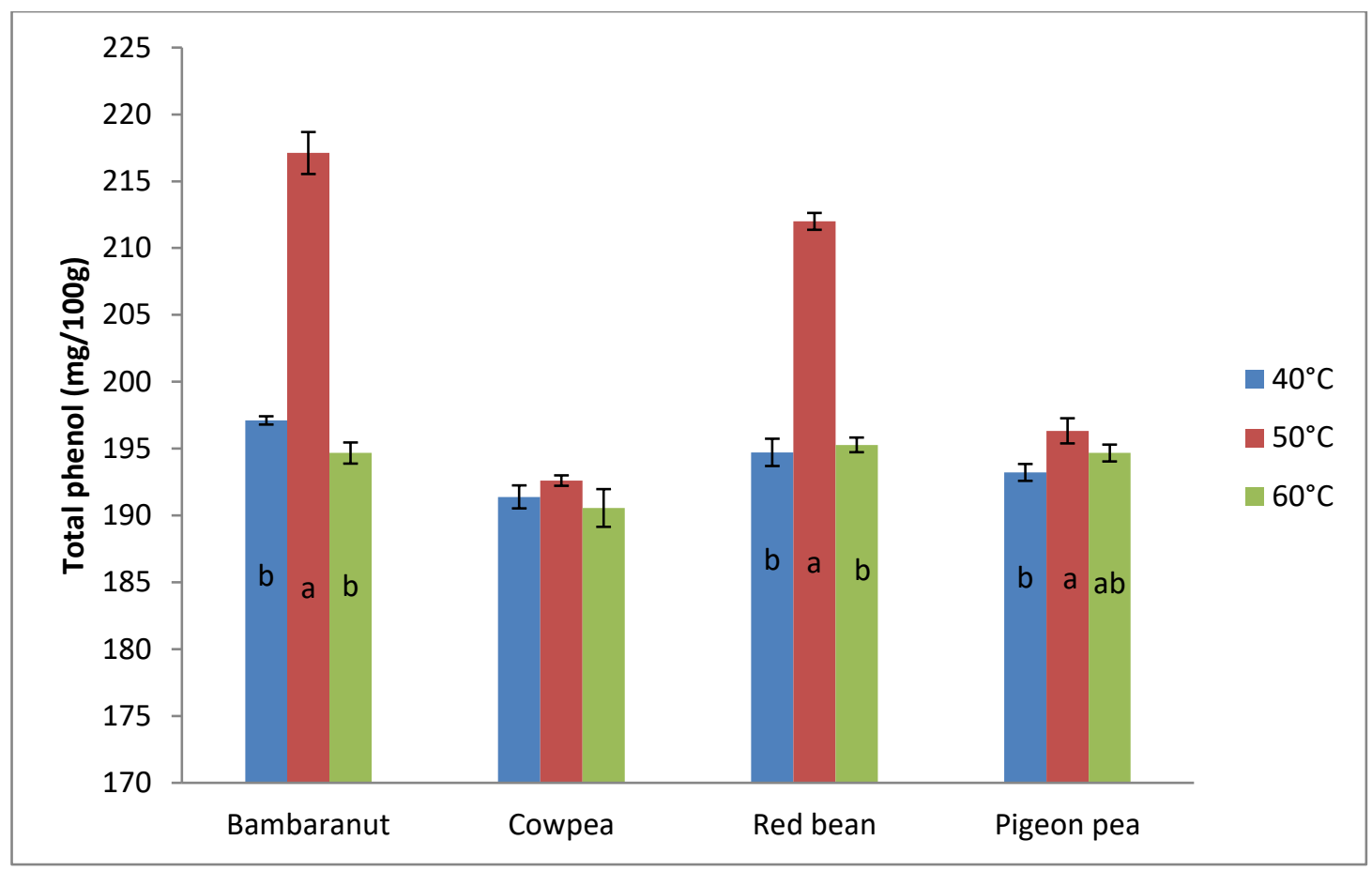

Fig. 7. Effect of extraction temperature on total phenol content

The selection of the most appropriate temperature for the recovery of the highest total phenol in a single factor experiment marked the end of the evaluation of extraction variables. Extraction temperature has been reported to significantly increase phenolic solubility, diffusion coefficient, reduce solvent viscosity, improve the rate of mass transfer and increase the rate of solvent penetration into the plant matrix and these favourably accelerate the recovery/yield of total phenol (Tan et al., 2013; Silva et al., 2007; Hemwimon et al., 2007). The result of this study shows that there was a steady increase in the total phenol content with a corresponding increase in temperature from 194.72 to $212.00 \mathrm{mg} / 100 \mathrm{~g}, 197.11$ to $217.11 \mathrm{mg} / 100 \mathrm{~g}$ and 193.22 to $194.67 \mathrm{mg} / 100 \mathrm{~g}$ in bambaranut, red bean and pigeon pea, respectively. The increase in total phenol observed in this study from 40 to $50{ }^{\circ} \mathrm{C}$ extraction temperature could be attributed to increasing solubility and diffusion coefficient of the phenolic compounds, adequate mass transfer and penetration of solvent into the plant matrix, disruption of phenolic-macromolecule complex as well as softening of the plant matrix for easy penetration of mild heat and solvents adopted for this study (Al-Farsi and Lee, 2008; Wang et al., 2008; Tan et al., 2013; Shi et al., 2005). However, at $60{ }^{\circ} \mathrm{C}$ extraction temperature, there was a significant decrease in the total phenol content. This trend agrees with the findings of Liyana-Pathirana and Shahidi (2005) and Tan et al. (2013) who reported that elevating the extraction temperature to a certain level might result in the concurrent disruption of the total phenol mobilised at low temperature. Furthermore, Cacace and Mazza (2003), Tan et al. (2013) and Abad-Garcia et al. (2007) asserted that extraction at elevated temperature causes the degradation of polyphenolic compounds, their polymerization with other molecules and occurrence of an internal redox reaction, which significantly reduce its total recovery.

\section{Conclusion}

For maximum yield of total phenol it is therefore recommended that bambaranut is extracted in $60 \%$ ethanol $(\mathrm{v} / \mathrm{v})$ for $40 \mathrm{~min}$ at $50{ }^{\circ} \mathrm{C}$, cowpea in $90 \%$ ethanol (v/v) for $50 \mathrm{~min}$ at $50{ }^{\circ} \mathrm{C}$, red bean in $100 \%$ methanol for $40 \mathrm{~min}$ at $50{ }^{\circ} \mathrm{C}$ and pigeon pea in $100 \%$ methanol (v/v) for $40 \mathrm{~min}$ at $50{ }^{\circ} \mathrm{C}$.

\section{Acknowledgements}

All the authors cited in this study are gratefully acknowledged.

\section{References}

Abad-Garcia, B., Berrueta, L.A., Marquez, D.M.L., Ferrer, I.C., Gallo, B. and Vicente, F. (2007): Optimization and validation of methodology based on solvent extraction and liquid chromatography for the simultaneous determination of several polyphenolic families in fruit juices. J. of Chromato 1154, 87-96. https://doi.org/10.1016/j.chroma.2007.03.023 
Achieng, D. and Odeny, D.A. (2007): The potential of pigeonpea (Cajanus cajan (L.) Millsp.) in Africa. Nat Res Forum 31, 297-305. https://doi.org/10.1111/j.1477-8947.2007.00157.x

Achuba, F.I. (2006): The effect of sub lethal concentration of crude oil on the growth and metabolism of cowpea (Vigna unguiculata) seedlings. The Environmentalist 21 (1), 17-20. https://doi.org/10.1007/s10669-0065354-2

Adams, M.W. (1984): Cowpea production constraint and national programmes. Bean/Cowpea Collaboration Research Support Programme. Michigan State University, East Lansing, USA.

Al-Farsi, M.A. and Lee, C.Y. (2008): Optimization of phenolics and dietary fibre extraction from date seeds. Food Chem 108, 977-985. https://doi.org/10.1016/j.foodchem.2007.12.009

Anwar, F. and Przybylski, R. (2012): Effect of solvents extraction on total phenolics and antioxidant activity of extracts from flaxseed (Linum usitatissimum L.). Acta Scientiarum Polonorum Technologia Alimentaria 11 (3), 293-302.

Bantilan, M.C.S. and Parthasarathy, D. (1997): Efficiency and sustainability gains from adoption of shortduration pigeonpea in non-legume-based cropping systems. International Crops Research Institute for the Semi-Arid Tropics, Patancheru, India.

Cacace, J.E. and Mazza, G. (2003): Optimization of extraction of anthocyanins from black currents with aqueous ethanol. Journal of Food Sci 68, 209-215. https://doi.org/10.1111/j.1365-2621.2003.tb14146.x

Chew, K.K., Ng, S.Y., Thoo, Y.Y., Khoo, M.Z., Wan Aida, W. and Ho, C.W. (2011): Effect of ethanol concentration, extraction time and extraction temperature on the recovery of phenolic compounds and antioxidant capacity of Centella asiatica extracts. Int. Food Res J. 18, 571-578.

Chirinos, R., Rogez, H., Campos, D., Pedreschi, R. and Larodelle, Y. (2007): Optimization of extraction conditions of antioxidant phenolic compounds from mashua (Tropaeolum tuberosum Ruiz) and pavon tubers. Separation and Purification Technol 55 (2), 217-225. https://doi.org/10.1016/j.seppur.2006.12.005

Enujiugha, V. (2010): The antioxidant and free radicalscavenging capacity of phenolics from African locust bean seeds (Parkia biglobosa). Advances in Food Sci 32 (2), 88-93.

Goli, A.H., Barzegar, M. and Sahari, M.A. (2004): Antioxidant activity and total phenolic compounds of pistachio (Pistachio vera) hull extract. Food Chem. 92, 521-525. https://doi.org/10.1016/j.foodchem.2004.08.020

Gupta, Y.P. (1988): Nutritive value of pulses. In: Baldev B, Ramanujam S, Jain HK (eds), Pulse crops. New Delhi: Oxford and IBH Publishing Company, India. pp 561601.

Hemwimon, S., Pavasant, P. and Shotipruk, A. (2007): Microwave assisted extraction of antioxidative anthraquinones from roots of Morinda citrifolia. Separation and Purification Techno. 54, 44-50. https://doi.org/10.1016/j.seppur.2006.08.014
Hu, F.B. (2003): Plant-based foods and prevention of cardiovascular disease: an overview. American $J$ of

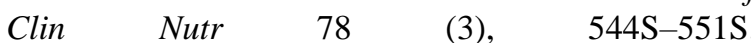
https://doi.org/10.1093/ajcn/78.3.544S

Jacobs, D.R. and Gallaher, D.D. (2004): Whole grain intake and cardiovascular disease: a review. Curr Atherosclerosis Rep 6, 415-423. https://doi.org/10.1007/s11883-004-0081-y

Kasote, D.M., Hedge, M.V. and Deshmukh, K.K. (2011): Antioxidant activity of phenolic components from nbutanol fraction (PC-BF) of defatted flaxseed meal. American J Food Technol. 6, 604-612. https://doi.org/10.3923/ajft.2011.604.612

Kraushofer, T. and Sontag, G. (2002): Determination of some phenolic compounds in flax seed and nettle roots by HPLC with colometric electrode array detector. European Food Res. Technol. 215, 529-533. https://doi.org/10.1007/s00217-002-0606-y

Kuljarachanan, T., Devahastin, S. and Chiewchan, N. (2009): Evolution of antioxidant compounds in lime residues during drying. Food Chem 113 (4), 944-949. https://doi.org/10.1016/j.foodchem.2008.08.026

Liyana-Pathirana, C.M. and Shahidi, F. (2005): Optimization of extraction of phenolic compounds from wheat using response surface methodology. Food Chem $93 \quad$ (1), 47-56 https://doi.org/10.1016/j.foodchem.2004.08.050

Lorenc-Kukula, K., Amarowicz, R., Oszmianski, J., Doerman, P., Starzycki, M., Skala, J., Zuk, M., Kulma, A. and Szopa, J. (2005): Pleiotropic effect of phenolic compounds content increases in transgenic flax plant. J. Agric. Food Chem. 53, 3685-3692. https://doi.org.10.1021/jf047987z

Naczk, M. and Shahidi, F. (2006): Phenolics in cereals, fruits and vegetables: Occurrence, extraction and analysis. Journal of Pharma and Biomedical Analy 41, 1523-42. https://doi.org/10.1016/j.jpba.2006.04.002

Nobre, C.P., Raffin, F.N. and Moura, T.F. (2005): Standardization of extract from Momordica charantia L. (Cucurbitaceae) by total flavonoids content determination. Acta Farm Bonaerense 24 (4), 526-566. http://www.latamjpharm.org/trabajos/24/4/LAJOP_24_4 3_1_UD5H2NZ4PV.pdf

NRC (2006): Lost Crops of Africa. Vegetables. National Research Council, Development, Security, and Cooperation Policy and Global Affairs, Volume II, Academic Press, Washington, New York, USA, pp. 354.

Nur Syukriah, A.R., Liza, M.S. Harisun, Y. and Fadzillah, A.A.M. (2014): Effect of solvent extraction on antioxidant and antibacterial activities from Quercus infectoria (Manjakani). Inter. J. of Food Res 21 (3), 1067-1073.

Onim, J.F.M., Semenye, P.P., Fitzhugh, H.A. (1985): Research on feed resources for small ruminants on smallholder farms in Western Kenya. In: Kategile, J.A., Said, A.N., Dzowela, B.H. (Eds.), Animal Feed Resources for Small-scale Livestock Producers. Proceedings of the second PANESA workshop, held in Nairobi, Kenya, pp 11-15. 
Pinelo, M., Sineiro, J. and Núñez, M.J. (2006): Mass transfer during continuous solid-liquid extraction of antioxidants from grape by-products. J of Food Engr 77 (1), 57-63. https://doi.org/10.1016/j.jfoodeng.2005.06.021

Platt, B.S. (1962): Tables of representative value of foods commonly used in tropical countries Med. Res. Council. Special edition report series No. 302, London, UK.

Rajha, H.N., Boussetta, N., Louka, N., Maroun R.G. and Vorobieva, E. (2014): A comparative study of physical pretreatments for the extraction of polyphenols and proteins from vine shoots. Food Res Inter 65, 462468. http://doi.org/10.1016/j.foodres.2014.04.024

Salem, A.A., Nahla, E.A., Al-Askalany, S.A. and Thabet, H. (2014): Effect of domestic processing methods of some legumes on phytochemical content and invitro bioavailability of some minerals. J of American Sci 10 (12), 276-287. http://www.jofamericanscience.org/

Salunkhe, D.K., Chavan, J.K. and Kadam, S.S. (1986): Pigeonpea as an important food source. Critical Reviews in Food Sci and Nutr 23 (2), 103-145. https://doi.org/10.1080/10408398609527422

Savita Rani, S., Poswal, G., Yadav, R. and Deen, M.K. (2014): Screening of pigeonpea (Cajanus cajan L.) seeds for study of their flavonoids, total phenolic content and antioxidant properties. Int. J. Pharm. Sci. Rev. Res. 28 (2), 90-94.

Shi, J., Nawaz, H., Pohorly, J., Mittal, G., Kakuda, Y. and Jiang, Y. (2005): Extraction of polyphenols from plant material for functional foods - Engineering and Technology. Food Re Inter 21, 139-166. https://doi.org/10.1081/FRI-200040606

Silva, E.M., Souza, J.N.N., Rogez, H., Rees, J.F. and Larondelle, Y. (2007): Antioxidant activities and polyphenolic contents of fifteen selected plant species from the Amazonia region. Food Chem. 101, 1012-1018. https://doi.org/10.1016/j.foodchem.2006.02.055

Singh B, Singh, J.P., Shevkani, K. and Singh, N. (2016): Bioactive constituents in pulses and their health benefits. J. Food Sci. Techno.

Steel, R.D.G., and Torrie, J.H. (1980): Principle and procedures of statistics. A biometrical approach. 2nd ed. McGraw Hill Co., New York, USA, Pp. 623.
Stephens, J.M. (2011): Bambara groundnut (Voandzeia subtterranea (L) Thouars). Gainesville, FL: University of Florida, IFAS Extension, USA

Sultana, B., Anwar, F. and Przybylski, R. (2007): Antioxidant activity of phenolic components present in barks of Azadirachta indica, Terminalia arjuna, Acacia nilotica, and Eugenia jambolana Lam Trees. Food Chem. 104, 1106-1114. https://doi.org/10.1016/j.foodchem.2007.01.019

Tan, M.C., Tan, C.P. and Ho, C.W. (2013): Effects of extraction solvent system, time and temperature on total phenolic content of henna (Lawsonia inermis) stems. Inter Food Res J. 20 (6), 3117-3123. http://www.ifrj.upm.edu.my/20\%20(06)\%202013/21\%2 OIFRJ\%2020\%20(06)\%202013\%20Ho\%20446.pdf

Towo, E.E., Svanberg, U. and Ndossi, G.D. (2003): Effect of grain pre-treatment on different extractable phenolic groups in cereals and legumes commonly consumed in Tanzania. J. Sci. Food Agric. 83, 980986. https://doi.org/10.1002/jsfa.1435

Wang, J., Sun, B.G., Cao, Y., Tian, Y. and Li, X.H. (2008): Optimization of ultrasound-assisted extraction of phenolic compounds from wheat bran. Food Chem. 106, 804-810. https://doi.org/10.1016/j.foodchem.2007.06.062

Wu, X., Beecher, G.R., Holden, J., Haytowitz, D., Gebhardt, S. and Prior, R. (2004): Lipophilic and hydrophilic antioxidant capacities of common foods in the United States. J. Agric. Food Chem. 52, 4026-37. https://doi.org/10.1021/jf049696w

Yao, D., Beket, Bonny, S. and Zoro Bi, I.A. (2005): Observations preliminaries de variabilite entre quelques morphotypes de voandzou (Vigna subterranea L. Verdc.) de Côte d'Ivoire. Biotechnologie, Agronomie, Sociètè et Environnement 9, 249-258.

Zhang, Z., Li, D., Wang, L., Ozkan, N., Chen, X.D., Mao, Z. and Yang, H. (2007): Optimization of ethanolwater extraction of lignans from flaxseed. Sep. and Purification Tech. $57 \quad$ (1), 17-24. https://doi.org/10.1016/j.seppur.2007.03.006 